\title{
Human Resource Management System Provides a Major Important Role to Develop Financial Sectors
}

\author{
Kazi Farhana Yeasmin \\ Faculty of Business Administration, Department of Accounting and Information Systems, Jagannath University, Dhaka, Bangladesh
}

Email address:

farhanaruna01@gmail.com

To cite this article:

Kazi Farhana Yeasmin. Human Resource Management System Provides a Major Important Role to Develop Financial Sectors. Journal of Human Resource Management. Vol. 3, No. 5, 2015, pp. 42-46. doi: 10.11648/j.jhrm.20150305.11

\begin{abstract}
Human Resource Management is a major important term for an organization, rest play an important backbone of the financial sectors. The Bangladesh Centre for Communication Program (BCCP), since evolving out of the Johns Hopking University/ Centre for Communication Program (JHU/ CCP) into an independent, self- sustaining organization has consistently striven to develop innovative strategic communication programs, revitalize its existing programs, and play a significant role in imparting training to thousands of workers. In this paper, I like to view the importance facts for develop the financial sector of an organization, and country. Now, in this technology world human resource management system became advanced and more efficiency that provides more difficult job beside machine. People do their job through using their thought, idea and many useful data. In the world many develop country such as USA, China, Japan, Australia, Europe, Russia gave more importance as well as doing more research on their human resource management system for develop their country. However, I have little experience on branch banking and financial sector. So, from my little experience can able to say that an advanced policy of the Human Resource Management system can make a new generation, as well as play an important role to enlarge the financial sectors of the country.
\end{abstract}

Keywords: Organizational Structure, Functioning, Motivation, Rationalization, Financial, Management, Human Resources, Strategy

\section{Introduction}

Human Resource Management (HRM) provides an institution with an effective work force in order to meet its mission. Effective human resource management uses systems and tools to bring together: the right number of people, with the right attitude and skills, in the right place, at the right time. Human Resource Management Model depends on some structure.

1. Human Resource Planning, 2.Human Resource Policies 3.Recruitment and Selection, 4.Salary, Benefits and Incentives, 5.Performance Management, 6.Training and Development.

Throughout these toolkits will learn about the functions and how, when applied appropriately, Human Resource Management can propel your institution toward success.

\section{Importance of Human Resource Management}

Every organization requires two major resources to operate: capital and people. The microfinance industry gives significant attention to the financial issues of operations. While finance is essential, it is only a tool in the hands of your people.

Money does not manage itself; people manage it.

Human Resource Management systems tools are critical in finding, training, managing, motivating, and developing a team of staff who will effectively carry out an organization's mission. By building strong, well functioning human resource systems and tools, institution will be poised for growth, ready to manage the challenges of an evolving environment, and responsive to the needs of your clients.

\section{Human Resource Management can Contribute to an Organization's Success}

All organizations are comprised of an interdependent network of individuals. In order for, any organization to be successful, the individuals within it must be productive, efficient, and effective. Attention to the management of these individuals can not only enhance the success of the individuals, 
but can encourage a team effort capable of reaching goals beyond what one person can do alone. All employees, regardless of their position in organization, need the same things to be successful. Some essential information needs to:

1. Identify with your organization's mission

2. Understand their role, and how that contributes to the mission

3. Know specifically what is expected of them

4. Have the capacity, resources, and environment which make success possible

5. Receive encouragement, constructive feedback, and opportunities to develop and improve

The effort of Human Resource Management is to implement systems and tools that will provide these key elements to help the individuals within an organization to be highly motivated and successful. When individuals are successful, an organization will be successful.

\section{HRM Provides Shape into the Organizational Chart}

It will be different for each organization and will depend on the size and structure of the institution. The mission, vision and culture of the organization will influence the role that HRM plays. In addition, HRM functions should be kept at a level that is appropriate to the organization's needs. As the institution grows, deciding how to manage HRM functions will evolve with the organization. Let's take a look at how HRM fits into various stages and sizes of organization operations.

\section{Best Organizational Structure}

Literature indicates that a flat, lean and simple organizational structure is the best model for a growing institution.

A "team business unit" approach should be considered to increase efficiency, productivity, and responsiveness to the target market. This could involve organizing your staff into teams by branch, different products, regions, or types of clients. Employees prefer working in smaller business teams where they find more challenging and interesting work and where there is a better chance to see their ideas adopted. Small teams also help to foster a higher sense of accomplishment.

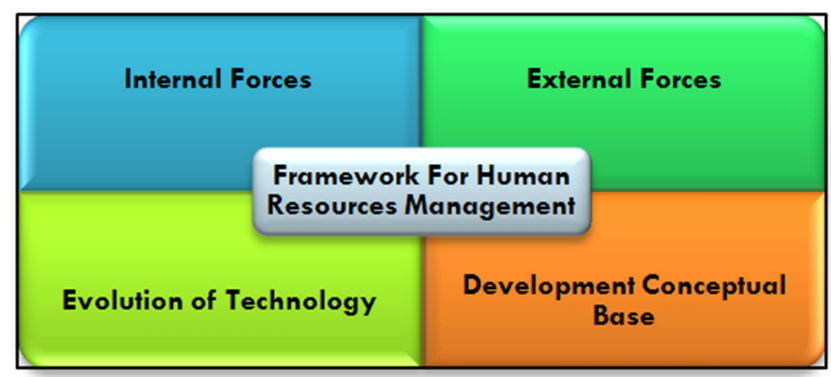

Figure 1. Framework for Human Resources Management.
An organizational structure that facilitates teamwork will increase your success and growth potential. Expanding organizations should create a dynamic, decentralized organizational structure that encourages strong branch offices. This works better than an organizational structure that grows in a hierarchical fashion.

The decentralization process, while critical to managing growth, can create administrative challenges; therefore, communication must remain an important element. The discussion below highlights how HRM functions are handled in a structure with decentralized branches.

\section{HRM Practices Are Consistently Applied Throughout the Financial Sectors}

The following tools and techniques are critical to ensure HRM practices are consistently applied throughout the Financial Sectors for develop the financial system.

\subsection{Good Systems}

Standardize and document HRM policies procedures, including clearly defined decision-making authority between head office and the branch offices (i.e. Personnel Policies; Recruitment Process; Performance Appraisals; Salary Administration, etc.)

\subsection{Training}

Ensure all staffs are trained on HRM policies and procedures. Training should be included in the orientation for new employees.

\subsection{Senior Management Support}

It is critical that senior managers not only recognize and advocate the importance of the HRM systems, but also model and use the systems themselves.

\subsection{Partnership}

HRM should take the role of an expert resource working in partnership with managers, supporting them in the application of HRM policies and procedures.

\subsection{Time Management}

- Good Systems

- Training

- Senior Management Support

- Partnership

- Time Management

- Communication
Good staff management takes time, and should be 
recognized in job descriptions and performance appraisals. Staff management should be a key responsibility integrated into management's responsibilities.

\subsection{Communication}

Regular communication between offices and team meetings with Branch Managers will help to recognize issues before they become problems, and encourage the exchange of ideas and solutions.

\subsection{Human Resource Policies}

Human Resource policies are the documented procedures and guidelines that provide structure to work expectations. These guidelines define the roles and responsibilities of both the organization and the employee. Topics such as work conditions, legal requirements (in accordance with local and national labor laws), salary administration, and many other issues are generally included in a written HR Policy Handbook. This section will define specific suggestions for writing, distributing and maintaining HR policies for your organization.

Human Resource policies provide consistency, fairness, and efficiency in dealing with staff. Having a written policy document also gives you the ability to establish and communicate the rights and responsibilities of the organization and your staff.

\section{Technological Advancement Era and Emergence of Strategic HRM (1990 to Present)}

The economic landscape underwent radical changes throughout the 1990s with increasing globalization, technological breakthroughs (particularly Internet-enabled Web services), and hyper competition. Business process reengineering exercises became more common and frequent, with several initiatives, such as right sizing of employee numbers, reducing the layers of management, reducing the bureaucracy of organizational structures, autonomous work teams, and outsourcing. Firms today realize that innovative and creative employees who hold the key to organizational knowledge provide a sustainable competitive advantage because unlike other resources, intellectual capital is difficult to imitate by competitors. Accordingly, the people management function has become strategic in its importance and outlook and is geared to attract, retain, and engage talent.

The increased use of technology and the changed focus of the HRM function as adding value to the organization's product or service led to the emergence of the HR department as a strategic partner. With the growing importance and recognition of people and people management in contemporary organizations, strategic HRM (SHRM) has become critically important in management thinking and practice. SHRM derives its theoretical significance from the resource-based view of the firm that treats human capital as a strategic asset and a competitive advantage in improving organizational performance.

Therefore, in determining the strategic fit between technology and HR, it is not the strategy per se that leads to competitive advantage but rather how well it is "implemented," taking into account the environmental realities that can be unique to each organization and, indeed, between units and functions of the organization.

\section{Interface Between HR and Technology}

The automation and redesign of work processes certainly help reduce costs and cycle times as well as improve quality. Management information systems (MIS) can further help decision makers to make and implement strategic decisions. However, IT is only a tool and can only complement, not substitute, the people who drive it. Often, organizations mistake IT as a message and not the messenger and divert time, effort, and money away from long-term investment in people to developing and deploying information technologies.

With the increasing use of information technologies in HR planning and delivery, the way people in organizations look at the nature and role of HR itself may change (Roehling et al., 2005). With HR data and reports now being readily available on their desktop, would managers interact less with the HR department and see it as being less important? If that is so, how would it affect the attitude of HR professionals toward their jobs and profession? Would they resist adoption of technology if they perceive that technology lessens their status? In traditional organizations with silo mentalities, turf wars between departments and functions acting as independent entities are common. Therefore, top management needs to be mindful of organizational politics in managing change. Through most of its evolution, HRM has had an administrative and caretaker focus in its delivery. With technology significantly decreasing the time required for administrative tasks, many HR professionals may find it difficult to redefine their jobs and may thus resist the change to an HRIS. This calls for redefining and transforming the role of HRM through value-added, strategic initiatives and interventions.

\section{A Model of Organizational Functioning}

Figure 1.2 illustrates a model of an organizational system centered on HRIS. This model depicts the interrelatedness of the parts of an organization that can affect the functioning of the organization. It shows the interrelatedness between the strategic management system, the strategic HRM system, and the performance goals, business and HR that are generated during the strategic planning process. Note; particularly how the business goals directly affect the HR goals and this relationship should be an ongoing process in an organization to make adjustments to either set of goals as needed. The HR goals drive the HR programs that provide management the tools for the efficient and effective use of employees.

First, this model is a framework to use in reading, organizing, and understanding the information given in this 
book. Second, this is a systems model; that is, it is organic and can change over time as represented by the feedback loops from goal achievement to other parts of the model. Third, the model is centered on the use of an HRIS as critical to the efficient operation of an organization.

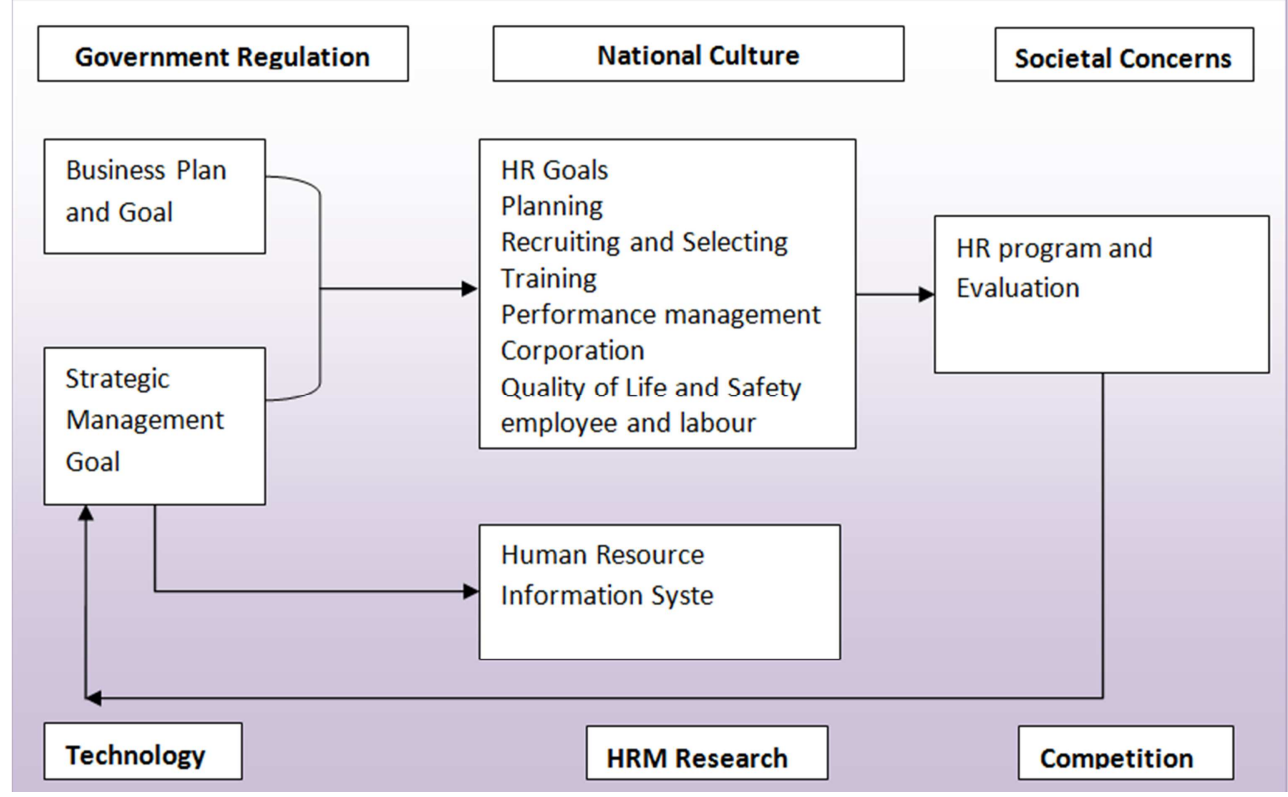

Figure 2. Model of Organizational Functioning.

\section{The Role of Human Resources in Training and Staff Development}

As a MFI continues to grow, it becomes important that a designated individual or entire department is assigned responsibility for training and development. In most MFIs, this person is part of the HRM Department. HRM can assume the following roles:

a. Develop and administer training policies.

b. Implement and support a Performance Management Process Implement and support a succession planning process implement a 360 degree review system Monitor personal development plans for all staff.

c. Identify needs for organization-wide training.

d. Provide counsel to staff/management on training and staff development options.

e. Monitor future HR trends.

f. Research and secure effective training programs.

g. Administer a system to track and approve staff training. Deliver training programs, contract trainers, or find appropriate training courses as required.

\section{HR Management System Policy Need To Develop in Bangladesh}

\subsection{Motivation, Rationalization, Opportunity}

Motivation may come from living beyond your means, racking up gambling debts, family illness or a host of other causes that give people sticky fingers. Rationalization is the self-talk that let people who steal tell themselves they're not doing anything all that wrong or, perhaps, convince themselves that they deserve to take the money from the company to balance out a perceived slight. Opportunity is the basically another one important theme that make an opportunity to develop Human Resource Management System. If the country or organizations don't involve the people into their working sector, then people could not achieve the knowledge about the policy and why policy is important term. Many organizations give an opportunity among some part of people but, that's immoral decision for the develop the Human Resource Management System.

\subsection{Improve Working Environment}

Environment policy is the number one as well as very important factor for develops Human Resources Management System. In Bangladesh have a major problem that many organization don't care on their working environment. Beside, many organization have less idea to do develop the environment system. There have less air filtering system and huge dust store in the organization place. Many local staff, employee working in the dust place, beside many organizations doesn't provide good food for the worker.

Moreover, female workers got torture in mentally and physical for force working. Sometimes, sexual harassment is happening on the female workers. Many organizations gave pressure to do working in the late night, beside abuse physically and sexual harassment.

\subsection{Low Opportunity to Apply Law}

There have very less opportunity to do apply criminal case for sexual harassment. Moreover, female cannot take help of law for frighten of the organization's high officially persons. 


\subsection{Proper Demand for Employer}

Looking at organization - level characteristics, the researchers found that firms with internal control weaknesses were more likely to have international sales, be undergoing restructuring and be involved in mergers and acquisitions.

According to Professor Steinbart, that problems identified by the team of scholars included, " lack of accounting personnel with sufficient knowledge in dealing with complex accounting and tax issues, inadequate overall security, deficiencies in design of information technology controls, insufficient disaster recovery plans " and failure to maintain effective control over separation of duties or access to financial reporting systems.

\section{Conclusions}

Human Resource Management System Provides a key important role to develop the financial sectors. In my article, I have trying to focus and discuss major area of human resource management system. I like to add many diagram and chart for understanding the human resources management policy. In this time and future human resource management system's demand is very important and provide a helpful activity that every organization and government will build many beneficial structures of human resource management system for adjusting the working cycles and environment.

\section{References}

[1] February 6, 2012, Professor Steinbart. "Risky business: Information systems research targets accounting threats".

[2] Social Science Research Network.

[3] August 2001. A Framework for Human Resources Management by International Civil Service Commission.

[4] April 2003, Robert M. Bushman and Abbie J. Smith. "Transparency, Financial Accounting Information, and Corporate Governance". (FRBNY Economic Policy Review /).

[5] November 2007, Kim Pityn and Jennifer Helmuth.

[6] Adapted by Graham A.N. Wright and Madhurantika Moulick. "Human Resource Management for MFIs Toolkit".

[7] June, 2015, issue; Financial Express Magazine.

[8] Abu Zafour. Human Resource Management Practices in Bangladeshi Organizations: A Case Study on Bangladesh Centre for Communication Program.

[9] Aurther, William, and Davis, Keith, "Human Resource Management", (9th edition), McGraw-Hill Book Company, New York, 2005. pp. 35-60.

[10] Hartmann, L.C. (1998). The impact of trends in labour-force participation in Australia. In M. Patrickson \& L. Hartmann (Eds.), Managing an ageing workforce (3-25). Warriewood, Australia: Woodslane Pty Limited. 